University of Nebraska - Lincoln

DigitalCommons@University of Nebraska - Lincoln

Faculty Publications: Department of Teaching, Department of Teaching, Learning and Teacher Learning and Teacher Education

Education

8-2013

\title{
Occupy: A case illustration of social movements in global citizenship education
}

Theresa Catalano

University of Nebraska-Lincoln, tcatalano2@unl.edu

Follow this and additional works at: https://digitalcommons.unl.edu/teachlearnfacpub

Catalano, Theresa, "Occupy: A case illustration of social movements in global citizenship education" (2013). Faculty Publications: Department of Teaching, Learning and Teacher Education. 139.

https://digitalcommons.unl.edu/teachlearnfacpub/139

This Article is brought to you for free and open access by the Department of Teaching, Learning and Teacher Education at DigitalCommons@University of Nebraska - Lincoln. It has been accepted for inclusion in Faculty Publications: Department of Teaching, Learning and Teacher Education by an authorized administrator of DigitalCommons@University of Nebraska - Lincoln. 
Published online September 6, 2013 (ahead of print) in Education, Citizenship and Social Justice,

DOI: $10.1177 / 1746197913497661$

Copyright $\odot 2013$ Theresa A Catalano; published by Sage Publications. Used by permission.

http://esj.sagepub.com

\title{
Occupy: A case illustration of social movements in global citizenship education
}

\author{
Theresa A. Catalano \\ Department of Teaching, Learning and Teacher Education, \\ University of Nebraska-Lincoln, Lincoln, NE 68588, USA. \\ email tcatalano2@unl.edu
}

\begin{abstract}
Due to the complex nature of global understanding and practice of citizenship, it is essential to understand how to educate for a responsive public sphere with active and emancipated citizens. This study aims to clarify how social movements (through a case illustration of Occupy) are representative of global citizenship goals while illuminating Occupy's main goals and dynamic nature. Data collection consisted of 45 interviews conducted at four different Occupy locations in the United States. Interviewee comments entwined with key elements representative of global citizenship education are outlined, and findings indicate not only how social movements can be an integral part of citizenship education but also shed light on a unique "we are here" movement that has transformed public discourse.
\end{abstract}

Keywords: Global citizenship education, Occupy, public pedagogy, social movements

\section{Introduction}

On September 17, 2011, Occupy, a leaderless, people-powered resistance movement, began in New York City and later spread to thousands of locations worldwide. From the time of its inception, the public's knowledge of the movement has largely stemmed from media reports that have varied from limited coverage to condescension (see Bellafante, 2011) to ridicule (see Burnett, 2011). Although the encampments are gone, the movement still continues. Still, many people limit their understanding to media reports and lack a true grasp of this social movement's aims and goals.

In the education arena, "many educators, policymakers, civil society organizations and parents are seeking models of education that inspire children, youth and teachers to take leadership in creating and enhancing a culture of democratic, active and inclusive citizenship" (Shultz et al., 2009). For some time, crucial links have been articulated among liter- 
Table 1. Key elements for responsible global citizenship. (Adapted from http://www.oxfam.org.uk/education/global-citizenship/key-elements-of-global-citizenship, accessed March 19, 2013)

\begin{tabular}{|c|c|c|}
\hline Knowledge and understanding & Skills & Values and attitudes \\
\hline Social justice and equity & Critical thinking & Sense of identity and self-esteem \\
\hline Diversity & Ability to argue effectively & Empathy \\
\hline $\begin{array}{l}\text { Globalization and } \\
\text { interdependence }\end{array}$ & $\begin{array}{l}\text { Ability to challenge injustice } \\
\text { and inequalities }\end{array}$ & $\begin{array}{l}\text { Commitment to social justice } \\
\text { and equity }\end{array}$ \\
\hline Sustainable development & Respect for people and things & Value and respect for diversity \\
\hline \multirow[t]{2}{*}{ Peace and conflict } & $\begin{array}{l}\text { Cooperation and conflict } \\
\text { resolution }\end{array}$ & $\begin{array}{l}\text { Concern for the environment } \\
\text { and commitment to } \\
\text { sustainable development }\end{array}$ \\
\hline & & $\begin{array}{l}\text { Belief that people can make a } \\
\text { difference }\end{array}$ \\
\hline
\end{tabular}

acy, democracy, empowerment, and social participation in politics and everyday life (see, for example, Dewey, 1882-1898/1974, 1897; Freire, 1996), and this case continues to be made (see, for example, Biesta, 2007; Giroux, 2002, 2006; Kellner and Share, 2007). Recent research examines what constitutes good citizenship (Westheimer and Kahne, 2004) as well as the role of Social Movement Oriented Citizenship (SMOC) in citizenship education (Edwards, 2012; Pizmony-Levy, 2007; Torney-Purta et al., 2008), but few studies actually illustrate exactly how social movements can be used as pedagogical tools of global citizenship education. Thus, this article has two aims: (1) to increase understanding of the essence of the Occupy movement by including perspectives of participants and (2) to demonstrate (using Occupy as a case illustration) how to incorporate the study of social movements as part of global citizenship education. In order to do this, the key elements of global citizenship will be outlined, along with a review of recent work on the incorporation of public pedagogy and social movements in global citizenship education. Then data collected from interviews conducted at four different Occupy locations in the United States in October and November, 2011 will be divided into themes relating to key elements of global citizenship education. These themes and key elements are then discussed in the context of interviewee comments, fulfilling the aims of explaining the movement from the point of view of its participants as well as using Occupy as a case illustration of how to teach global citizenship through the use of social movements.

\section{Social movements, public pedagogy, and global citizenship education}

In order to understand how to incorporate social movements into global citizenship education, we must first define global citizenship education. According to Rapoport (2010), although the term "global citizenship education" is used more and more frequently at academic conferences, and in various educational discourses, there is no consensus as to its meaning (p. 180). However, it is "usually conceptualized within the frameworks of international education, global education (Davies et al., 2005), multicultural education (Banks, 2004; Dunn, 2002), peace education (Smith and Fairman, 2005), human rights education (Gaudelli and Fernekes, 2004) or economic education" (as cited in Rapoport, 2010: 180). For the purposes of this article, the discipline of global citizenship education will be defined by Oxfam International's Guide for Education for Global Citizenship (Oxfam GB, 2006). ${ }^{1}$ Those elements of responsible global citizenship are mentioned in Table 1. 
Now that we have an idea of a common framework for what constitutes global citizenship education, "there is a need to explore how we can educate for a more vibrant public sphere with citizens who participate as activists and emancipated citizens" (Shultz and GuimaraesIosif, 2012). The work of Henry Giroux is particularly relevant in calling to attention the capability of the larger culture (meaning the public sphere) to out-do institutionalized education as the most important educational force in developed societies. According to Giroux (2004), transforming the pedagogical needs to become more political in the classroom, and the political needs to become more pedagogical outside of the classroom. This can be done through the harnessing of the educational force of the wider culture. Giroux (2002) implies that we need to encourage students to see themselves as actors in the political arena and attempt to merge "politics and ethics with a revitalized sense of the importance of providing the conditions for forms of critical citizenship and civic education that provide the knowledge, skills, and experiences to produce democratic political agents" (p. 96).

Building on Giroux's work, several recent studies have been carried out that document the reasons why we need to incorporate public pedagogy and use of social movements in citizenship education as well as what types of activities work better than others (Edwards, 2012; Pizmony-Levy, 2007; Torney-Purta et al., 2008). Pizmony-Levy (2007) used the International Association for the Evaluation of Educational Achievement (IEA) Cived dataset and investigated student- and country-level contributors to support social movement citizenship across 28 countries. Using hierarchical linear modeling (HLM), the study found that student support for conventional forms of citizenship, type of government, gender, and attention to news and discussions about international news are the strongest predictors of support for social movement citizenship. Torney-Purta et al. (2008) analyzed differences across countries in students' knowledge related to SMOC using the same dataset and methodology (HLM). They found that students with more knowledge of human rights, more frequent engagement with international topics and more open class and school climates held stronger norms supporting social movement citizenship, had more positive attitudes toward immigrants' rights and were more politically efficacious (p. 857). Another study by Edwards (2012), explained how SMOC, which centers on peaceful protest, proactive community involvement and participation in activities to support human rights and environmental protection can produce significant results in students. The study (conducted in Colombia) assessed the effects of school-related variables on SMOC and found that pedagogy and curriculum that encourage discussion, promote an open classroom climate, and implement a social movement-centered curriculum are positively and significantly related to the development in students of SMOC, while after school activities are not.

With regard to teacher awareness of global citizenship education and how to teach it, Rapoport (2010) (in a study of Indiana teachers' conceptions of global citizenship education) found that although teacher participants tried to deconstruct the concept of global citizenship, they fell short of mentioning citizenship as participation (p. 187). In addition, the study found that "education practitioners, even those who are genuinely committed to teaching from a global perspective, need clear curricular guidance" and "teachers need more rigorous methodological, content, and curricular assistance to teach emerging types of citizenship" (Rapoport, 2010: 187). Although the above studies describe the link between social movements and global citizenship education, few studies have explored exactly how to incorporate social movements pedagogically into curriculum, hence this study seeks to fill this gap in the literature through the case illustration of Occupy.

\section{Method}

In-depth 30-minute interviews were conducted by the author with individuals or small groups in Zuccotti Park, Manhattan, New York, on October 13, 2011; Centennial Park Mall, 
Lincoln, NE on October 21, 2011; Sproul Hall (University of California (UC), Berkeley campus) on November 10, 2011; and in Oscar Grant Plaza (in front of city hall) in Oakland, California, on November 11, 2011. The original research plan was to conduct interviews in Zuccotti Park alone, but after the movement spread to many other locations, I decided to try to interview at as many locations as possible. Therefore, since I live in Lincoln, Nebraska, the choice of Occupy Lincoln was a natural one. The choices of Occupy Cal and Occupy Oakland were also due to circumstance, as I happened to be attending a conference there in November, and thus, I took advantage of my visit to conduct more interviews. Interestingly enough, I found that each site had a different rationale for why participants were there (i.e. in Occupy Oakland, many participants addressed police brutality, while in Occupy Cal, students largely discussed tuition rises) and a somewhat different tone, which is why I have included the interview locations when listing interviewee comments. I stayed at interview sites on average from 4 to 8 hours, depending on the number of willing participants that were found. The number of participants varied for each site and included 18 from Zuccotti Park, 12 from Occupy Oakland, 9 from Occupy Cal, and 6 from Occupy Lincoln for a total of 45 interviews. Participants met the purposeful sampling criteria of being a participant in Occupy, available at the time of the interviews and agreeing to be interviewed. Participants ranged in age, gender, ethnicity, and nationality as well as stated reasons for participation in the movement. The Institutional Review Board (IRB) at my institution approved participant consent when individuals in Occupy agreed to be interviewed. Reciprocity involved a dialogic approach in which participants asked the researcher-interviewer questions in return for providing answers. According to Guion et al. (2011), in-depth interviews feature the following four key characteristics: open-ended questions, semistructured format, a goal of seeking clarity and understanding, and audio-recorded responses with notes (p. 1). These interviews involve not only asking questions but also systematically recording and documenting the responses to probe for deeper meaning and understanding (Guion et al., 2011). In keeping with this framework, two open-ended questions were designed for the interviews, and the researcher encouraged follow-up questions and dialog. The questions were as follows:

1. Why are you here? (at the Occupy site).

2. What do you hope to achieve?

The questions were designed as a way to get behind the movement's real purposes and to give protesters a chance to be heard. The interviews were conducted as a conversation more than a question/answer period, and I spent a great deal of time talking to participants off the record before and after the interviews. Interviews were conducted in English and Spanish and recorded on an iPad using the application "Quick Voice Pro." Audio-recordings of interviews were transcribed (and in some cases, translated from Spanish into English) by the author. Transcribed interviews were imported to MaxQDA (qualitative data analysis software) and run through a word list to rank lexical items according to frequency. Once this list was produced, the most frequent words were coded into MaxQDA and a lexical analysis was run through the data to determine other lexical items that collocated with the highly frequent words. These lists were then examined manually searching for patterns, taking notes, and recoding the words according to these patterns. From this search, a set of major themes was determined and matched to relevant key elements of global citizenship education listed in Oxfam's guide for schools on the development of global citizenship education (Oxfam GB, 2006). 


\section{Key elements of global citizenship education: Voices from Occupy Wall Street}

\section{Knowledge and understanding}

One of the most important themes of both global citizenship education and Occupy is the knowledge and understanding of social justice and equity issues. It is no surprise that many of the participants addressed these elements in their interviews, as it was identified early on in the movement as one of the key reasons for its inception. Here are some comments from Occupy participants in Zuccotti Park (and one from Occupy Lincoln) in answer to the questions "Why are you here?" and "What do you hope to achieve?":

- ... Mainly I think, at its core, people are demanding a just, fair society and people understand that that's not what we have.

- I'm here because I'm disenfranchised by the current political system in the United States - why this community and we're here because it's conducive to social justice you know, that's the idea that we're here because we want things to change ...

- There's a variety of things to achieve. One would be to get Citizen's United overturned. We've got to get the corporations out of the elections.

- Equality! I want it to be like it was in the nineties when Clinton was around and gas was $\$ 1.00$ something. I know something's wrong with the government but I'm not sure exactly what it is. It's just not the same as it was. Maybe because I was younger and more naïve but actually I just got health care a year ago and they're already talking about taking it away. There's not any opportunities for our generation, we're basically forgotten.

- ... The role of money in government decisions, the inequality in our economic system, rising economic disparity, rich get richer, poor get poorer, cuts in the government for health care and education and things that are basic human rights while CEOs and corporations are doing just fine ...

According to Gitlin (2012), “A serious social movement is one that makes the political personal in a thousand ways, even as a core of the most passionate decide whether and where and how to take to the streets" (p. 228). The above comments from Occupy participants illustrate the personal sense of injustice and inequality that united many and led them to join the movement. In fact, "one of the movement's greatest successes has been simply to put the inequalities of everyday life on the national agenda, influencing reporting, public perception and language itself" (Chomsky, 2012: 9). Case and point, it is now nearly impossible to hear the word "occupy" and not think of the Occupy movement (Alim, 2011). Ironically, the term "occupy" has been used to reshape how the world thinks about issues of democracy and equality, by taking a term formally used to refer to nations, armies and police who occupy (usually by force):

Now, it signifies progressive political protest. It's no longer primarily about force of military power; instead it signifies standing up to injustice, inequality and abuse of power. It's no longer about simply occupying a space; it's about transforming that space. (Alim, 2011)

With regard to global citizenship education, the interviewee comments illustrate what Westheimer and Kahne mean by justice-oriented civic education. That is, being able to crucially assess social, political and economic structures; seek out and address areas of injus- 
tice and know about social movements and how to affect systemic change (Westheimer and Kahne, 2004: 240). In addition, students studying about Occupy through interviewing (or reading interviews with participants) gain the opportunity to learn about current laws and issues affecting the public such as Citizen's United (mentioned in six interviews). Curriculum based on social movements such as Occupy can and should include interviews with real participants that "encourage students to question a system's origins and whose voices are heard, but also to move to various forms of action" (Edwards, 2012: 119). The inclusion of comments from individuals involved in historical events in order to bring them alive is not unusual in Social Studies textbooks. Consider the following from America's History, a history textbook designed for high school juniors:

From the very inception of America's History, we set out to write a democratic history, one that would convey the experiences of ordinary people even as it recorded the accomplishments of the great and powerful. We focus not only on the marvelous diversity of peoples who became American but also on the institutions - political, economic, cultural, and social - that forged a common national identity. (Henretta et al., 2004: vii)

Thus, educational research such as this, that make social movements come alive through the voices of its participants are not only necessary but should be harnessed by global citizenship teachers and social studies teachers in general.

A second element of knowledge and understanding that is important in global citizenship education is the idea of globalization and interdependence. The following interviewee (from Zuccotti Park) comment addresses this issue:

We have the responsibility that we have entered into, that's the world we live in, the tiniest kind of the tiniest change in one place has the effect, you know it's like the butterfly effect that expands across continents, like a volcano in Iceland has affected the entire world, the stock market in one country, the economy crashing in one country has affected the economy in the entire world. So, we need to take this principle and really begin to apply it in our daily lives and interpersonal connections and international relationships and in everything that we do, and that's the attitude that we come to the table with and we make sure that everyone's taken care of and there's not a single person, not a single country that is kind of left out in the cold, as something that you would not do with a member of your family. Because that's what we are at this point, we're a global family, we're a small global village, and we need to take care of every member of this family as if they are truly our brothers and sisters because they really are. That's what the world is showing us right now, that's what nature is showing us. All systems in nature are integral, they're interconnected and they're mutually responsible they're interdependent and they work together in harmony.

This comment draws on the increasing awareness that uneven globalization (which creates wider gaps between the rich and poor) increases environmental destruction, hunger, and militarization to protect the interests of local, regional, and global elites (Shultz and Guimaraes-Iosif, 2012: 242). Moreover, this participant (like many of those interviewed) understands and appreciates the interdependence and connection of humanity to one another. In fact, many of the participants interviewed expressed joy in the continual human connection and face-to-face interaction they experienced camping out and living in such close proximity to another during the movement's peak, an element that for many of the participants has been missing in today's technology-dependent world. Additionally, the above comment illustrates the transnational nature of this movement defined by Tarrow and McAdam (2005) as "sustained contentious interactions with opponents - national or non-na- 
tional - by connected networks of challengers organized across national boundaries." Just as in other transnational social movements such as Seattle's anti-globalization movement (which was event-based and dissolved soon afterward), the transnational Occupy movement faced many obstacles to its endurance such as the varying goals and approaches of many of its localized participants (i.e. in Oakland where solidarity was valued over the nonviolence principle) (Gitlin, 2012: 120; Tarrow, 2011a: 255). The above comment also illustrates the fact that movements are social organisms - "living phenomena that breathe in and adapt to their environments, not objects frozen into their categories while taxonomists poke and prod them" (Gitlin, 2012: 141). Hence, since interviews for this article were conducted in October and November of 2011, they represent the early stages of the movement and the excitement of participants as Occupy added coalitions around the globe and felt the speed and momentum as it built a global coalition of contention.

\section{Skills}

In addition to knowledge and understanding, mediation skills such as the ability to argue, debate, persuade, negotiate consensus or agree to differ are also important elements of global citizenship education (Oxfam GB, 2006). In the following excerpt from a multipleparticipant interview in Zuccotti Park, the participants demonstrated and developed their ability to argue and articulate the goals of the movement: ${ }^{2}$

P17: This community is an example of a democracy in a very pure form.

P16: We are self-sustaining, self-governing.

R: $\quad$ But you don't have power.

P16: We do have power. That's exactly what we're proving right now.

P17: Yeah, we do have power. Why are you here then?

R: $\quad$ So what are you going to do with it?

P17: I don't want to do too much with it.

P16: I want to take our power to govern ourselves and stop letting other people tell us what to do and govern us for us.

R: But how are we going to make that come about?

P16: $\quad$ By proving that we can govern ourselves. Take this sanitation thing ...

P17: By setting an example. There are Occupies in 80 countries right now. Which is definitely showing that there's something inspiring about what's happening here ...

Besides revealing the importance of the ability to argue/debate in social movement participation, the above interview demonstrates how interviews can be used as a gateway to understanding social events such as Occupy. Moreover, this conversation illustrates how interviews aid in the forming and articulating of opinions for those being interviewed. According to Greenfield (2010), "transformative interviewing techniques deliver the possibility of uncovering valuable information as well as functioning as the genesis for the development of greater consciousness ...." As the interviewer, I had the chance to converse with participants in the movement and gain a first-hand perspective on what was actually happening. In the process, I became part of the movement itself (note the use of "we" in the final question), and part of the international dialog that has been opened by the protesters. In fact, after completing one of my interviews, I took the time to converse with the interviewees further about the need to express specific goals to the media. One of the interviewees took me aside afterward and said "Thank you. You are one of the only people that has stayed after the interview and really listened to us and dialogued with us. That is really all we wanted - just to be heard." This comment brings forward the cultural role that educational research can and should play 
in informing practice, along with the technical role that evidence-based research brings (Biesta, 2007). This cultural role helps educational practitioners (such as in my case) to acquire a different understanding of their practice, and imagine it differently. Thus, it is transformative. According to Biesta, a democratic society is one in which social research is not restricted to a technical role but can also perform a cultural one. A democratic society is characterized by the existence of an open and informed discussion about problem definitions and the aims and ends of our educational endeavors (Biesta, 2007).

Another important skill to be incorporated in global citizenship education is that of cooperation and conflict resolution. According to Massaro and Stryker (2011), "incivility in discourse poses a problem for democracy" (p. 375). The following comment by an Occupy Lincoln participant speaks to the recent calls for civil discourse and the inability for politicians and policymakers to cooperate and solve problems:

About the time that the Tea Party movement came in, we lost our ability to talk to each other, debates devolved, people stopped being able to communicate, there were a lot more shouting matches and I thought, you know what? We tell the little kids on the playground to use their words, to talk to each other, and if they don't do that, then they fight. This is how we break up fights. If we can't talk to each other, than this is going to devolve into fist gusts. Like this is going to become really ugly really nasty. To me, this movement is incredibly helpful. It's people saying, we gotta go back to talking. We gotta go back to people, not dollars. We gotta go back to thinking about what's fair what works for everybody.

As stated by Judith Butler (1993), "Performative acts are forms of authoritative speech: most performatives, for instance, are statements, which, in the uttering, also perform a certain action and exercise a binding power" (p. 17). Performatives include not only statements that perform an action but also those that confer a binding power on the action performed. Thus, performatives are one domain in which power acts as discourse (Butler, 1993). Thus, through the comments of Occupy participants, we can see the performative nature and recursivity of talking about needing to talk. Hence, the very act of participants being interviewed and protesters meeting with media and holding marches and meetings engages them in the very processes that they are wanting to improve, although it did not necessarily lead to people in power improving their ability to cooperate and solve problems. However, Occupy participants did demonstrate through nonviolent contentious collective action their ability to cooperate with each other (through use of the Internet and social media and on site in their various locations with their own rituals and language of participation). In addition to addressing concerns about learning how to communicate, the above participant also mentions the Tea Party, which has frequently been compared to Occupy. According to Gitlin (2012), the two movements are not symmetrical. At the time these interviews were conducted, the Tea Party was equally popular to the Occupy Movement, and equally polarizing. But popularity was more important to the Tea Party than to Occupy, whose thrust was largely electoral, and was more disruptive and utopian (Gitlin, 2012: 41). Academics such as Sidney Tarrow (2011b) contend that Occupy is a new type of social movement, not comparable to the Tea Party or other seemingly similar social movements. The Tea Party "was created to serve specific constituencies, such as white middle-class Americans who saw themselves as victims of an over-weaning federal government" (Tarrow, 2011b). In contrast, Occupy put forward few policy proposals and had a shifting configuration of supporters as it spread across the country. Thus, according to Tarrow, it could be referred to as a "we are here" movement, asking only to be recognized and acknowledged, such as in the following comment from an interviewee at Occupy Cal (UC Berkeley): 
Why I'm here and what do I hope to achieve? Well, I'm here just, sort of to be a body because the more people that are here the more media coverage it gets and then also the more power we have as a voice. And what do I hope to achieve? Uhm, I guess mostly that. Is to try and to say we are here, we are disgruntled.

One testament to the success of Occupy is the amount to which it has been compared to other social movements such as the above-mentioned Tea Party but also the Seattle antiglobalization movement, Civil Rights Movement, Spain's 15M, and more recently, Italy's M5S (Movimento Cinque Stelle) (Mueller, 2013). ${ }^{3}$ While I believe that there are similarities to each of these movements, data collection from this study (as seen in the above comment) supports Tarrow's conclusions that Occupy is a unique social movement that stands on its own, which is one reason why it contains such educational value, particularly in the area of global citizenship education.

\section{Values and attitudes}

The final category of key elements in global citizenship education is that of valuing and respecting diversity, as well as having a positive attitude toward diversity and difference. One important subcategory of values and attitudes is that of having empathy and a sense of common humanity with others. The following comments illustrate how some participants of Occupy became empathetic toward others during the movement:

- I feel like I'm able to stand alongside with like, my brothers and sisters across borders, like this isn't just national, this isn't just occupy wall street, this is like an occupation on the international financial institutions ... (Occupy Lincoln)

- I'm here because many of my friends are here and my students and I think that their ideas are correct and that they're defending important causes ... public education and public services generally which are being scrapped. And I have known reckless police intervention on this campus before and I would like to be here on the side of my students if that happens. (Occupy Cal-UC Berkeley)

The first comment points to a recognition that people are united in their belonging to a broken system controlled by corporations and that the "people who go to work producing things we need - the middle class and working poor - pay the price for all this" (Gelder, 2011: 4). The second comment is illustrative of the support and empathy that some communities had (such as many Berkeley professors) for the participants (in this case, their students) in the movement and the suffering caused by things such as tuition increases. In addition to empathy, Occupy participants demonstrated a commitment to social justice and equity. The following comments give voice to Occupy Oakland, where "raw police violence has clashed for decades with a ready population of militants ..." (Gitlin, 2012: 115). Arguably one of the more violent locations for the Occupy movement, many participants there were subjected to a great deal of police brutality. The first comment speaks to the commitment to equity in terms of poverty and how unaffordable college tuition has become, whereas the second addresses the commitment to social justice against police brutality:

- I read in the paper that there is thirty-three and a third percent more poverty in the last decade and on the same page there was things saying Wells Fargo paid no taxes last year. It's horrifying. And also because I went to UC Berkeley and my tuition was never more than $\$ 200$ and now it's like 12,000. And so, you know these kids keep getting up and saying they owe all this money and there's no jobs ... it's just nuts. 
- I'm here because I'm asking the mayor, city council and police department to stop using violence against people at Occupy Oakland and the people who are using their first amendment rights to ask for economic justice ...

Another important subcategory of values and attitudes is valuing and respecting diversity. The following comments from Zuccotti Park reflect the diverse nature of the participants and gives voice to Latinos and some of their reasons for participating:

- I, as a Latino, and a resident of the city of New York, I'm here participating in the occupation of Wall Street because we Latinos, we are one of the communities most affected by the economic crisis. Our problems are much more elevated than other communities. Health insurance is inaccessible for our community ...

- First of all, I'm here because I'm Latin American and as a Latin American I belong to a minority group in American society and also as a worker and as a professor, I'm here because we believe this movement it's necessary to get the support of all types of people that believe in a more just world.

The teaching of human rights should underpin global citizenship education in multicultural nation states (Osler and Starkey, 2006: 17) and comments such as those listed above highlight how the Latino community in the United States, and in particular, Latino migrants have suffered under the financial crisis. Moreover, the incorporation of interviews with members of minority groups into global citizenship curriculum creates empathy, which aids in bringing about respect and value for people from different ethnic, socio-economic, cultural, and linguistic backgrounds.

In addition to respect for diversity, concern for the environment and commitment to sustainable development are important goals of global citizenship education as well as a prevalent theme throughout the interviews. Given below is a small sample of those comments from Zuccotti Park:

- ... so it's really important to sort of shift to a new value system that can brings us into the future without destroying the planet and it might actually bring us happiness.

- ... It's young people who are realizing that our planet is at a very precarious point and you can't trust the old systems anymore and this is the birthplace for something I hope will take hold for our planet. I don't want to voice it but I do worry for the planet ... I've been very concerned about our planet and it's a long time until people wake up.

Finally, the belief that people can make a difference is crucial to the implementation of a global citizenship education. The following comments (from Zuccotti Park) express this hope and belief in the power of the people:

- I see this movement as an assertion of the people's power and I want to be a part of it. I think that we have an incredibly important message to send to the people in the country and the world and I think that everybody's finally ready to listen because things are bad enough.

- My dream would of course to be to see this spreading across the world and hope that it would be become a big enough movement that it would really, uhm enact change in law and change in fundamental systems.

It was not uncommon in Occupy interviews to see references to what has gone wrong in representative democracy, and the fact that elected politicians no longer represent the will of the people. The belief that people can make a difference (and change the system) became 
a driving force to unite participants toward these goals. Thus, the "collective challenges based on common purposes and social solidarities, in sustained interaction with elites, opponents, and authorities" demonstrated in Occupy represent the basic properties of social movements and provide an excellent model of participatory democracy for students (Tarrow, 2011a: 9).

\section{Conclusion}

As Rapoport (2010) notes, "the tendency to incorporate global, international and comparative perspectives into citizenship education is on the rise" (p. 186). The Occupy movement serves as an excellent case illustration of SMOC, and this article has demonstrated how interviews with participants can be used in the classroom to teach essential elements of global citizenship education such as knowledge, understanding, and commitment to social justice, equity, and diversity; skills such as the ability to argue effectively, cooperation, and conflict resolution; and values and attitudes such as empathy, concern for the environment, and a belief that people can make a difference. Not only has this study described how Occupy embodies the essence of the educational goals for global citizenship, but it has also provided an opportunity to understand the movement from the point of view of its participants. As a consequence, we can now see that this movement represents the very ideals of a participatory democracy. As a "we are here" movement, interviews revealed that one of the main goals of the movement was to bring dialog to the table about the inequalities of the "system." As Shen Tong likes to say (former leader of Tianmen Square movement), "A social movement can be crushed by two kinds of crisis: one kind is a massacre, the other is success" (Gitlin, 2012: 232). In the case of Occupy, the success is evident in the transformation, within a few weeks, of America's political discourse regarding the topic of the inequality of wealth, which is now widely recognized and denaturalized (Gitlin, 2012). Subsequently, Occupy should be seen as an example of a (largely) peaceful manifestation of a contentious collective action that made a difference, and furthermore, by incorporating the study of Occupy (and other social movements) into global citizenship education, there lies great power in encouraging students to take part in social movements or activities "aimed at the betterment of society and the environment" (Edwards, 2012: 125).

Acknowledgments - I would like to thank Margaret Macintyre Latta for her ongoing encouragement, support, and advice throughout the writing process. In addition, I would like to thank Isabella Catalano, Lauren Gatti, George Lakoff, Kristen Nugent, and Paula Mcavoy for their helpful suggestions and advice. This research received no specific grant from any funding agency in the public, commercial, or not-for-profit sectors.

\section{Notes}

1. Oxfam International is an "international confederation of 17 organizations networked together in more than 90 countries, as part of a global movement for change ..." (from http://www.oxfam. org/en/about).

2. Participants are labeled with " $\mathrm{P}$ " and a number representing the order in which they were interviewed, while the researcher is labeled "R."

3. Movimento Cinque Stelle (5 Star Movement) is an Italian social movement led by Beppe Grillo (a comedian and social critic) that won a quarter of the Italian popular vote in February 2013 to become the leading party in the lower house of parliament. According to Mueller (2013), had Occupy Wall Street produced a leader with long-term vision, and a manifesto of concrete goals, it might have resembled Movimento Cinque Stelle (albeit it exists in a very different political context). 


\section{References}

Alim, S. (2011) What if we occupied language? New York Times, December 21, 2011. Online at http://opinionator.blogs.nytimes.com/2011/12/21/what-if-we-occupied-language/

Bellafante, G. (2011) Gunning for Wall Street with faulty aim. The New York Times, September 23, 2011. Online at http://www.nytimes.com/2011/09/25/nyregion/protesters-are-gunning-forwall-street-with-faulty-aim.html?_r=2

Biesta, G. (2007) Why "what works" won't work: Evidence-based practice and the democratic deficit in educational research. Educational Theory 47(1): 1-22.

Burnett, E. (2011) CNN's Erin Burnett “Seriously?!" Occupy Wall Street, Commentary, October 4, 2011. Online at http://www.youtube.com/watch?v=\&ndash;pvo3yV8Y8\&feature=related

Butler, J. (1993) Critically queer. GLQ: A Journal of Lesbian and Gay Studies 1: 17-32.

Chomsky, N. (2012) Occupy. London: Penguin Books.

Dewey, J. (1882-1898/1974). The Early Works of John Dewey, ed. J. A. Boydston. Carbondale, IL: Southern Illinois University Press.

Dewey, J. (1897) My Pedagogic Creed. New York: E. L. Kellogg \& Co.

Edwards, D. B. (2012) Social movement oriented citizenship in Colombia: the effects of curriculum, pedagogy and extra-curricular activities on student orientation. Education, Citizenship and Social Justice 7: 117-128.

Freire, P. (1996) Pedagogy of the Oppressed. New York: Continuum.

Gelder, S. V., ed. (2011) This Changes Everything: Occupy Wall Street and the 99\% Movement. San Francisco, CA: Berrett-Koehler Publishers, Inc.

Giroux, H. (2002) Educated hope in an age of privatized visions. Cultural Studies: Critical Methodologies 2(1): 93-112.

Giroux, H. (2004) Public pedagogy and the politics of neo-liberalism: making the political more pedagogical. Policy Futures in Education 2(3-4): 494-503.

Gitlin, T. (2012) Occupy Nation: The Roots, the Spirit, and the Promise of Occupy Wall Street. New York: HarperCollins.

Greenfield, D. (2010) “When I hear Afrikaans in the classroom and never my language, I get rebellious": Linguistic apartheid in South African higher education. Language and Education 24(6): 517-534.

Guion, L., Diehl, D., and McDonald, D. (2011) Conducting an in-depth interview. FCS6012. Department of Family, Youth and Community Sciences, Florida Cooperative Extension Service, Institute of Food and Agricultural Sciences, University of Florida. Online at http://edis.ifas.ufl.edu/ pdffiles/FY/FY39300.pdf

Henretta, J., Brody, D., Dumenil, L., et al. (2004) America's History. Boston, MA/New York: Bedford/St. Martin's.

Kellner, D., and Share, J. (2007) Critical media literacy is not an option. Learning Inquiry 1: 59-69; DOI 10.1007/s11519-007-0004-2.

Massaro, T., and Stryker, R. (2011) Freedom of Speech Liberal Democracy and Emerging Evidence on Civility and Effective Democratic Engagement. National Institute for Civil Discourse. Online at http://nicd.arizona.edu/research-articles

Mueller, T. (2013) What Beppe Grillo wants. The New Yorker. Online at http:/ / www.newyorker. com/online/blogs/newsdesk/2013/03/beppe-grillo-is-serious.html (accessed March 19, 2013).

Osler, A., and Starkey, H. (2006) Education for democratic citizenship: A review of research, policy and practice 1995-2005. Research Papers in Education 24: 433-456. 
Oxfam GB (2006) Education for global citizenship: a guide for schools. Oxfam GB. Online at http:// www.oxfam.org.uk/education/global-citizenship/key-elements-of-global-citizenship (accessed March 19, 2013).

Pizmony-Levy, O. (2007) Youth support for social movements in twenty eight countries. Paper presented at the annual meeting of the American Sociological Association, New York, August 11, 2007.

Rapoport, A. (2010) We cannot teach what we don't know: Indiana teachers talk about global citizenship education. Education, Citizenship and Social Justice 5: 179-190.

Shultz, L. and Guimaraes-Iosif, R. (2012) Citizenship education and the promise of democracy: A study of UNESCO associated schools in Brazil and Canada. Education, Citizenship and Social Justice 7: 241-254.

Shultz, L., Guimaraes-Iosif, R., Chana, T., et al. (2009) The Impact of Becoming a UNESCO ASPnet School in Alberta and Manitoba. Edmonton, AB, Canada: Alberta Teachers' Association. Online at http://www.teachers.ab.ca/SiteCollectionDocuments/ATA/Publications/Professional-Development/MON-1\%20The\%20Impact\%20of\%20Becoming\%20a\%20UNESCO.pdf

Tarrow, S. (2011a) Power in Movement: Social Movements and Contentious Politics (Revised and originally published in 1994, 1998). Cambridge: Cambridge University Press.

Tarrow, S. (2011b) Why Occupy Wall Street is not the tea party of the left. Foreign Affairs. Online at http://www.foreignaffairs.com/articles/136401/sidney-tarrow/why-occupy-wall-street-is-notthe-tea-party-of-the-left (accessed March 19, 2013).

Tarrow, S., and McAdam, D. (2005) Scale shift in transnational contention. In: Della Porta, D., and Tarrow, S., eds. Transnational Protest and Global Activism. Lanham, MD: Rowman \& Littlefield, ch. $6,121-150$.

Torney-Purta, J., Wilkenfeld, B., and Barber, C. (2008) How adolescents in 27 countries understand, support, and practice human rights. Journal of Social Issues 64(4): 857-880.

Westheimer, J., and Kahne, J. (2004) What kind of citizen? The politics of educating for democracy. American Educational Research Journal 41(2): 237-269. 